\title{
Construction of recombinant sestc Saccharomyces cerevisiae for consolidated bioprocessing, cellulase characterization, and ethanol production by in situ fermentation
}

\author{
Peizhou Yang ${ }^{1}$ (I) Haifeng Zhang $^{1} \cdot$ Shaotong Jiang ${ }^{1}$
}

Received: 24 May 2016/ Accepted: 28 August 2016/Published online: 3 September 2016

(c) The Author(s) 2016. This article is published with open access at Springerlink.com

\begin{abstract}
Bioethanol is an important oil substitute produced by the sugar fermentation process. To improve the efficiency of cellulase expression of Saccharomyces cerevisiae, a eukaryotic expression vector harboring a singleenzyme-system-three-cellulase gene (sestc) was integrated into the $S$. cerevisiae genome by the protoplast method. Using PCR screening, RT-PCR, and "transparent circle" detection, several recombinant $S$. cerevisiae strains, capable of efficiently expressing the heterogeneous cellulase, were selected. The total activity of cellulase, endo- $\beta-D-$ glucanase, exo- $\beta$-D-glucanase, and xylanase of the recombinant $S$. cerevisiae transformant (designated number 14) was $1.1,378,1.44$, and $164 \mathrm{U} \mathrm{ml}^{-1}$, respectively, which was 27.5-, 63-, 24-, and 19-fold higher than that of the wild-type strain. The concentration of ethanol produced by the engineered $S$. cerevisiae strain was $8.1 \mathrm{gl}^{-1}$, with wheat bran as the carbon source, under submerged conditions; this was 57.86 -fold higher than that produced by the wild-type strain $\left(0.14 \mathrm{gl}^{-1}\right)$.
\end{abstract}

Keywords Saccharomyces cerevisiae $\cdot$ Cellulase $\cdot$ Sestc gene $\cdot$ Engineering strain $\cdot$ Ethanol $\cdot$ In situ fermentation

Peizhou Yang

yangpeizhou@163.com; peizhou3@illinois.edu

1 The Key Laboratory for Agricultural Products Processing of Anhui Province, College of Food Science and Technology, Hefei University of Technology, Tunxi Road 193, Hefei 230009, Anhui, China

\section{Introduction}

In recent years, with the dramatic increase in demand for petroleum, natural gas, coal, and other non-renewable energy sources has necessitated the development of solutions to the fossil energy crisis (Saini et al. 2015). Biomassderived fuel obtained by converting lignocellulose into ethanol represents an attractive alternative source of energy. This process requires the application of three key technologies: pretreatment of raw material, saccharification, and fermentation. The saccharification process is highly dependent on the synergistic actions of cellulase and hemicellulase. One of the main components of enzymatic hydrolysis production is glucose, which may be used for ethanol production by the yeast Saccharomyces cerevisiae (Tiboni et al. 2014).

Wild-type $S$. cerevisiae possesses extremely low cellulase activity under general conditions. The bottleneck of simultaneous glycosylation and fermentation may be overcome by increasing the cellulase activity of $S$. cerevisiae (Zerva et al. 2014). Cellulase activity can be improved by two techniques: the first method involves the integration of a single cellulase system gene, e.g. $c b h$ (Haan et al. 2013), e.g. (Baek et al. 2012), and bgl (Tang et al. 2013) were individually integrated into the $S$. cerevisiae chromosome. In practice, the degradation of lignocellulose complexes via the overexpression of a single cellulase system gene has proven difficult. The second method, which involves co-expression of multiple cellulase genes in S. cerevisiae, has been found to be highly effective in degrading the hard structure of lignocelluloses. Several combinations of cellulase-encoding genes such as Trichoderma reesei egi/Saccharomycopsis fibuligera bgli (Haan et al. 2007), T. reesei e.g. II/Aspergillus aculeatus bgl (Fujita et al. 2002), three $\beta$-glucosidase (BGL) genes and 
two endoglucanase (EG) genes from Aspergillus oryzae (Kotaka et al. 2008), Endomycopsis fibuliger bgll/Butyrivibrio fibrisolvens endl/Phanerochaete chrysosporium cbh1/Ruminococcus flavefaciens cell (Rensburg et al. 1998), and T. reesei egII/T. reesei cbhII/A. aculeatus bgll (Fujita et al. 2004) was used to increase the efficiency of decomposition of recalcitrant lignocelluloses. Because it is difficult to maintain the expression of several cellulase genes at an identical level, the use of a cellulase cocktail should enable optimal decomposition (Yamada et al. 1978). Therefore, the development of an engineered strain harboring a single enzyme system that incorporates the activity of multiple cellulases would be extremely useful to achieve synergistic and efficient degradation of cellulose.

The conversion of lignocellulosic biomass into fuels by in situ fermentation is promising. The degradation of lignocellulosic material, composed of cellulose and hemicelluloses, requires the action of multiple enzymes capable of hydrolyzing the recalcitrant lignocellulose structure into reducing sugars. These cellulolytic and xylanolytic enzymes include EGs, exoglucanases, BGLs, and xylanase, which cleave cellobiose or oligosaccharide units into glucose and xylose monomers. The consolidation of several processes involving cellulase production, lignocellulose hydrolysis, and fermentation during bioprocessing is difficult, which leads to high costs of biomass production and low economic efficiency. Consolidated bioprocessing, in which these three key processes are combined into a single step, represents a promising alternative approach. The strategies involved in consolidated bioprocessing include the native cellulolytic strategy and the recombinant cellulolytic strategy (Lynd et al. 2005). The feasibility of consolidated bioprocessing using a recombinant strategy depends on the combination of fermentation and reduction in the reactivity of saccharification of the substrate (Walsum and Lynd 1998). To overcome this bottleneck, cellulases, xylanases, and amylases have been expressed in various S. cerevisiae strains (Katahira et al. 2004). In addition, engineered $S$. cerevisiae strains have been used for the functional expression of several cellobiohydrolases (Hong et al. 2003).

The single-enzyme-system-three-cellulase gene (sestc), isolated from Ampullaria gigas Spix, encodes a three-cellulase system comprising the endo-beta-1,4-glucanase, exo-beta-1,4-glucanase, and xylanase enzymes (Shujie et al. 2009), and was also found to be a multifunctional cellulase gene. In this study, an expression vector harboring the sestc gene was integrated into the $S$. cerevisiae chromosome using a PEG-mediated protoplast genetic integration technique. The characteristics of the extracellular enzyme produced by successful transformants were investigated and the activity of the three-cellulase system (comprising endo-beta-1,4-glucanase, exo-beta-1,4- glucanase, and xylanase) was studied. In addition, the production of ethanol was investigated under submerged conditions with wheat bran as carbon source.

\section{Materials and methods}

\section{Genes, expression vector, strain, and lytic enzyme}

The reading frame of the eukaryotic expression plasmid was based on that of the pBlueScript II KS vector (Fig. 1). The glyceraldehyde-3-phosphate dehydrogenase gene $(g p d)$ promoter, isolated from Enoki Mushroom (em-gpd), was adopted (Yang et al. 2011). The sestc gene was isolated from the stomach tissue of A. gigas. The hygromycin resistance gene $(h p h)$ was used as the selectable marker gene. The industrial strain of $S$. cerevisiae was maintained at a laboratory at the College of Food Science and Engineering, Hefei University of Technology. The lytic enzyme for protoplast preparation was obtained from the Microorganism Preservation Center of Guangdong province.

\section{Genetic integration and molecular identification}

The expression vector was integrated into the $S$. cerevisiae chromosome randomly using the protoplast transformation method. A standard colony of $S$. cerevisiae was inoculated into $50 \mathrm{ml}$ of YPD broth medium obtained from Sangon Biotech containing $1 \%$ yeast powder, $2 \%$ peptone, and $2 \%$ glucose, at $30{ }^{\circ} \mathrm{C}$, with shaking at $180 \mathrm{rpm}$, for $48 \mathrm{~h}$ in a $250 \mathrm{ml}$ Erlenmeyer flask. Then, $5 \mathrm{ml}$ of fermentation broth was removed and centrifuged at $800 \mathrm{rpm}$ at $4{ }^{\circ} \mathrm{C}$ for 5 min using a centrifuge manufactured by Backman Company; the solid cells were collected and washed three times with ultrapure water. Next, $1 \mathrm{ml}$ of $2 \%\left(\mathrm{wv}^{-1}\right)$ lywallzyme was added to a sterilized $10 \mathrm{ml}$ Eppendorf tube manufactured by Haimen United Laboratory Equipment Development Co., Ltd. The broth was incubated at $30{ }^{\circ} \mathrm{C}$, with shaking at $80 \mathrm{rpm}$ for $1 \mathrm{~h}$, and the $S$. cerevisiae protoplast thus obtained was observed using an optical microscope (Olympus Microscope CX21) with a magnification of $\times 400$. When the protoplast concentration reached $80 \%$, the enzymatic reaction was gradually decreased through dilution in threefold of the solution volume using sorbitol/ $/ \mathrm{CaCl}_{2}(\mathrm{~S} / \mathrm{C})$ solution prepared with $0.6 \mathrm{~mol} 1^{-1}$ $\mathrm{KCl}$ pre-cooling solution, $1 \mathrm{M}$ sorbitol, and $50 \mathrm{mmol}^{-1}$ $\mathrm{CaCl}_{2}$. Three layers of qualitative filter paper manufactured by Yancheng Yongkang Lab Instruments Factory, China were used to remove the cell debris and other large fragments produced by enzymatic hydrolysis. The filtrate was centrifuged at $800 \mathrm{~g} \mathrm{rpm}$ in $4{ }^{\circ} \mathrm{C}$ for $10 \mathrm{~min}$ using a Beckman Coulter Allegra 64R refrigerated centrifuge to 


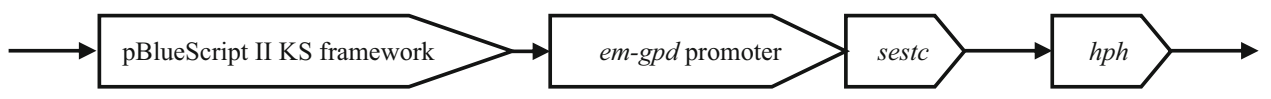

Fig. 1 The structure of the reading frame of the expression vector

precipitate the protoplast, and the supernatant was discarded. The collected cells were washed and precipitated using S/C solution. After centrifugation, the protoplasts were suspended in $50 \mu \mathrm{l}$ of $\mathrm{S} / \mathrm{C}$ solution. The expression plasmid $(10 \mu \mathrm{g})$ was added to a protoplast suspension of $100 \mu \mathrm{l}$; this was supplemented with $50 \mu \mathrm{l}$ of polyethylene glycol (PEG) buffer and gently mixed using a pipette. After placing in an ice bath for $20 \mathrm{~min}, 1 \mathrm{ml}$ of PEG buffer (prepared with $25 \%$ PEG8000, $50 \mathrm{mmol} \mathrm{l}^{-1} \mathrm{CaCl}_{2}$, and $10 \mathrm{mmol}^{-1}$ Tris $\mathrm{HCl}$, at $\mathrm{pH} 7.5$ ) was added to the reaction mix. The reaction was incubated at $20^{\circ} \mathrm{C}$ for $5 \mathrm{~min}$; then, $2 \mathrm{ml}$ of $\mathrm{S} / \mathrm{C}$ solution was added and the reaction system was gently mixed. After a $10 \times$ dilution, the solution was evenly coated on to solid regeneration medium containing $0.3 \%$ yeast powder, $1 \%$ peptone, $2 \%$ glucose, $0.6 \mathrm{~mol} \mathrm{l}^{-1} \mathrm{MgSO}_{4}$, and $1.8 \%$ agar, and incubated for 24-72 $\mathrm{h}$ at $30^{\circ} \mathrm{C}$. Then, a single colony was picked for analysis by PCR. The primers used for amplification of partial fragments of the sestc gene, by PCR and RT-PCR, were as follows: primer R: 5'-GCTTCAGTCAAGCGCATGCC-3'; primer F: 5'-GTCGGCGGCGTGTGCGATACG- $3^{\prime}$. The PCR reactions were performed in a $30 \mu \mathrm{l}$ total volume containing $20 \mu \mathrm{l}$ of sterile deionised water, $3 \mu \mathrm{l}$ of $10 \times$ Taq DNA polymerase, $3 \mu \mathrm{l}$ of $2 \mathrm{mM} \mathrm{dNTP}$,

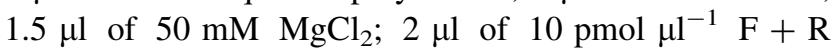
primer stock; $0.4 \mu \mathrm{l}$ of DNA (approximately $20 \mathrm{ng}$ per reaction minimum), $0.25 \mu \mathrm{l}$ of Taq DNA polymerase. The PCR program was as follows: step 1 at $94{ }^{\circ} \mathrm{C}$ for $10 \mathrm{~min}$, step 2 at $94{ }^{\circ} \mathrm{C}$ for $40 \mathrm{~s}$, step 3 at $64{ }^{\circ} \mathrm{C}$ for $30 \mathrm{~s}$, step 4 at $72{ }^{\circ} \mathrm{C}$ for $1 \mathrm{~min}$, step 5 repeat step $2 \times 3$ times, step 6 at $94{ }^{\circ} \mathrm{C}$ for $40 \mathrm{~s}$, step 7 at $56^{\circ} \mathrm{C}$ for $30 \mathrm{~s}$, step 8 at $72{ }^{\circ} \mathrm{C}$ for 1 min, step 9 at $6 \times 35$ times, step 10 at $72{ }^{\circ} \mathrm{C}$ for $10 \mathrm{~min}$, and step 11 at $4{ }^{\circ} \mathrm{C}$ indefinitely.

\section{Calculation of sizes of transparent circles as a measure of the strength of cellulase activity}

Solid sodium carboxymethyl cellulose medium consisting of $0.2 \% \mathrm{NaNO}_{3}, 0.1 \% \mathrm{~K}_{2} \mathrm{HPO}_{4}, 0.05 \% \mathrm{MgSO}_{4}, 0.05 \% \mathrm{KCl}$, $0.2 \%$ sodium carboxymethyl cellulose, $0.02 \%$ peptone, and $1.7 \%$ agar powder, was prepared. The surface of the solid sodium carboxymethyl cellulose medium containing Petri dish was evenly divided into four zones using a marker pen. A single hole of $5 \mathrm{~mm}$ diameter was made in each zone. Then, $5 \mathrm{ml}$ of culture medium was centrifuged at $3577.6 \times g$ at $4{ }^{\circ} \mathrm{C}$ for $15 \mathrm{~min}$ in $10 \mathrm{ml}$ centrifuge tubes. The supernatant $(100 \mu \mathrm{l})$ was absorbed and added to the previously made hole in the solid culture medium. This volume was added to each hole. After incubation for $5 \mathrm{~h}$ at $30{ }^{\circ} \mathrm{C}$, iodine solution, containing $6 \%$ potassium iodide and $3 \%$ iodine, was prepared. The formation of transparent circles, which indicated cellulase activity, was observed for a period of $15 \mathrm{~min}$. The formation of transparent circles indicated the production of reducing sugars owing to the decomposition of sodium carboxymethyl cellulose by cellulase; the larger the transparent circle formed, the stronger the cellulase activity. The sizes of the transparent circles were calculated by determining the difference between the diameter of the outer transparent circle $(\mathrm{h})$ and that of the inner slotting holes (s) (Fig. 2). This method enabled the identification of colonies of true transformants harboring the cellulase gene.

\section{Fermentation and cellulase expression}

The colonies of wild-type $S$. cerevisiae and transformants were separately inoculated into $50 \mathrm{ml}$ of seed media (prepared with $10 \mathrm{gl}^{-1}$ sodium carboxymethyl cellulose, $20 \mathrm{gl}^{-1}$ peptone, and $10 \mathrm{gl}^{-1}$ yeast powder sterilized at $121{ }^{\circ} \mathrm{C}$ for $20 \mathrm{~min}$ ) in a $250 \mathrm{ml}$ Erlenmeyer flask at $30{ }^{\circ} \mathrm{C}$ with shaking at $150 \mathrm{rpm}$ for $36 \mathrm{~h}$. Then, $3 \mathrm{ml}$ of the media was taken out and transferred into $100 \mathrm{ml}$ of liquid fermentation medium, prepared with $20 \mathrm{gl}^{-1}$ wheat bran, $20 \mathrm{gl}^{-1}$ peptone, $10 \mathrm{gl}^{-1}$ yeast powder, and $5 \mathrm{gl}^{-1}$ glucose, sterilized at $121{ }^{\circ} \mathrm{C}$ for $20 \mathrm{~min}$, in a $250 \mathrm{ml}$ Erlenmeyer flask. The culture was incubated for $24 \mathrm{~h}$ at $30{ }^{\circ} \mathrm{C}$ with shaking at $150 \mathrm{rpm}$. Next, $3 \mathrm{ml}$ of the culture was collected every $6 \mathrm{~h}$ to evaluate the total activity of cellulase, endobeta-D-glucosidase, exo-beta- glucosidase, and xylanase.

\section{Characterization of the cellulase enzyme produced by the transformants}

The transformants forming the largest transparent circles, as described in Sect. "Calculation of sizes of transparent circles as a measure of the strength of cellulase activity", were selected for characterization of the total activity of cellulase, endo- $\beta$-D-glucosidase, exo- $\beta$-D-glucosidase, and xylanase. Cellulase characteristics, such as the optimum reaction temperature and $\mathrm{pH}$, thermal and acid stability, and the effects of metal ions such as $\mathrm{K}^{+}, \mathrm{Mn}^{2+}, \mathrm{Zn}^{2+}$, $\mathrm{Cu}^{2+}, \mathrm{Fe}^{2+}$, and $\mathrm{Fe}^{3+}$, were investigated.

\section{Measurement of cellulase and xylanase activity}

The activities of total cellulase, endo- $\beta$-D-glucosidase, exo- $\beta$-D-glucosidase, and xylanase were measured using 
Fig. 2 The calculation of the sizes of the transparent circle formed in the solid culture medium

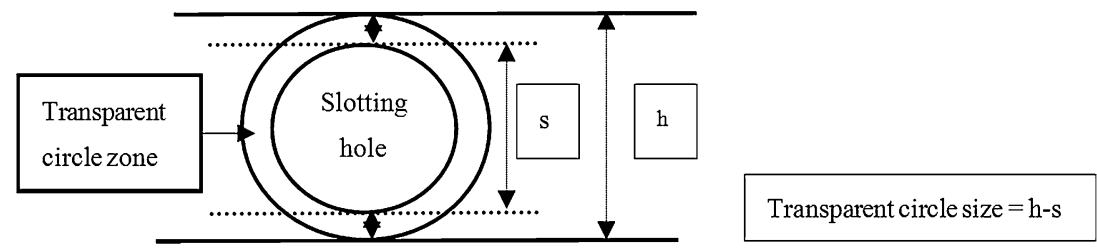

filter paper, sodium carboxymethyl cellulose, microcrystalline cellulose, and xylan as substrates, respectively. The dinitrosalicylic acid (DNS) method was used, and one enzymatic activity unit was defined as that required for the generation of $1 \mu \mathrm{mol}$ of glucose or xylose per min in $1 \mathrm{ml}$ of enzyme solution (IUPAC 1987; Zhang et al. 2009; Nummi et al. 1985).

\section{Preparation of fermentation media and in situ fermentation for ethanol production}

Using wild-type $S$. cerevisiae as the control, a transformant designated number 14 was used to detect ethanol production by submerged fermentation. The wild-type colonies and those of transformant number 14 were inoculated into a $250 \mathrm{ml}$ Erlenmeyer flask containing $50 \mathrm{ml}$ seed media [which consisted of $5 \%$ glucose, $2 \%$ peptone, $0.5 \%$ $\left(\mathrm{NH}_{4}\right)_{2} \mathrm{SO}_{4}$, and $\left.0.1 \% \mathrm{MgSO}_{4}\right]$ and incubated at $30{ }^{\circ} \mathrm{C}$ for $36 \mathrm{~h}$ at $150 \mathrm{rpm}$. Then, $10 \mathrm{ml}$ of broth was added to a $250 \mathrm{ml}$ Erlenmeyer flask containing $50 \mathrm{ml}$ of fermentation media [adjusted to $\mathrm{pH} 6.0$, containing $4 \mathrm{~g}$ of rice straw, $1 \mathrm{~g}$ of wheat bran, $0.4 \mathrm{~g}$ of $\left(\mathrm{NH}_{4}\right)_{2} \mathrm{SO}_{4}, 0.6 \mathrm{~g}$ of $\mathrm{KH}_{2} \mathrm{PO}_{4}, 0.1 \mathrm{~g}$ of $\mathrm{CaCl}_{2}, 0.1 \mathrm{~g}$ of $\mathrm{MgSO}_{4}, 0.1 \mathrm{~g}$ of $\mathrm{MnSO}_{4}, 0.1 \mathrm{~g}$ of $\mathrm{ZnSO}_{4}$, and $0.1 \mathrm{~g}$ of $\left.\mathrm{Cocl}_{2}\right]$. After $48 \mathrm{~h}$ of incubation at $30{ }^{\circ} \mathrm{C}$ with shaking at $150 \mathrm{rpm}$, the system temperature of the fermentation culture was increased to $50{ }^{\circ} \mathrm{C}$ for $2 \mathrm{~h}$. The temperature was then decreased to $30{ }^{\circ} \mathrm{C}$, while fermentation continued during incubation at $150 \mathrm{rpm}$ for $36 \mathrm{~h}$. The amount of yeast cells in broth were counted to calculate the survival rate of thermal treatment (Rikhvanov et al. 2003). Ethanol concentration was determined using the gas chromatography method (Sree and Sridhar 1999).

\section{Results and discussion}

\section{Preparation of S. cerevisiae protoplasts}

The concentration of the S. cerevisiae protoplasts were calculated by microscopy. The $S$. cerevisiae protoplast concentration was nearly $80 \%$ after a 60 min treatment of lytic enzyme. After treatment for over $105 \mathrm{~min}$, the protoplast concentration exceeded $90 \%$ (Fig. 3).

Figure 4 shows the relationship between regeneration frequency and protoplast concentration for S. cerevisiae. When the protoplast concentration reached $90 \%$, the

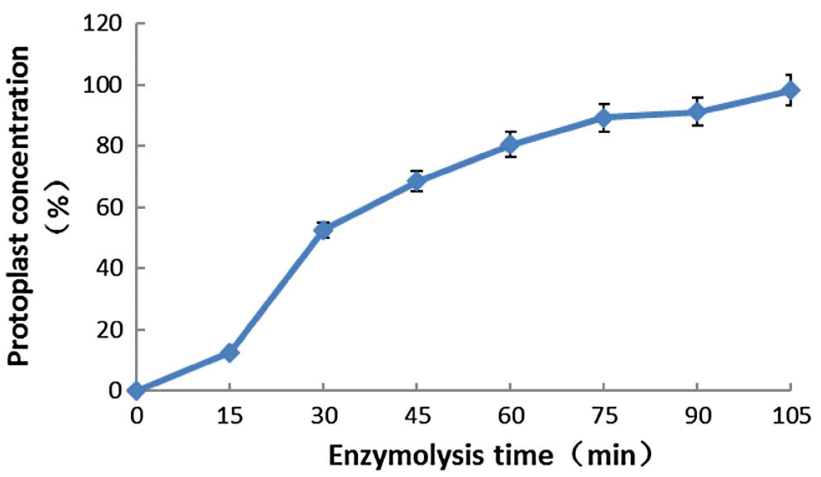

Fig. 3 Relationship between protoplast concentration and duration of enzymolysis

regeneration frequency decreased to $64 \%$. At higher concentrations, the protoplasts were more easily broken under a given centrifugation pressure. In addition, the protoplasts were easily damaged or torn by pipettes during transformation and mixing. Insufficient digestion by the lytic enzyme and excessive treatment both led to a decrease in efficiency of genetic transformation. In this study, to avoid severe injury to protoplasts due to excessive enzymolysis, enzymatic hydrolysis was terminated after $60 \mathrm{~min}$. Residual lytic enzyme attached to yeast cells was removed by centrifugation and washing. The regeneration frequency is a key index for genetic transformation of microorganisms, and optimal conditions for protoplast formation vary between species and strains (Zhang et al. 2016). For S. cerevisiae, reversion frequencies reached $50 \%$ on agar-solidified media (Svoboda 1966). Sorbitol (1 M) was applied to regeneration agar, and a PEG-mediated transformation method was used to improve the transformation efficiency (Zhang et al. 2016). In addition to supplementation with sorbitol and PEG, $\mathrm{CaCl}_{2}$ and Tris $\mathrm{HCl}$ were used to improve the efficiency of protoplast regeneration.

\section{Screening of hygromycin concentration and $S$. cerevisiae protoplast regeneration}

The growth of $S$. cerevisiae on YPD-hygromycin B media was investigated. S. cerevisiae is generally sensitive to hygromycin B. The numbers of colonies on solid media, with the addition of various hygromycin B concentrations, were counted (Table 1). Protoplast growth of S. cerevisiae was seriously inhibited when the concentration of 


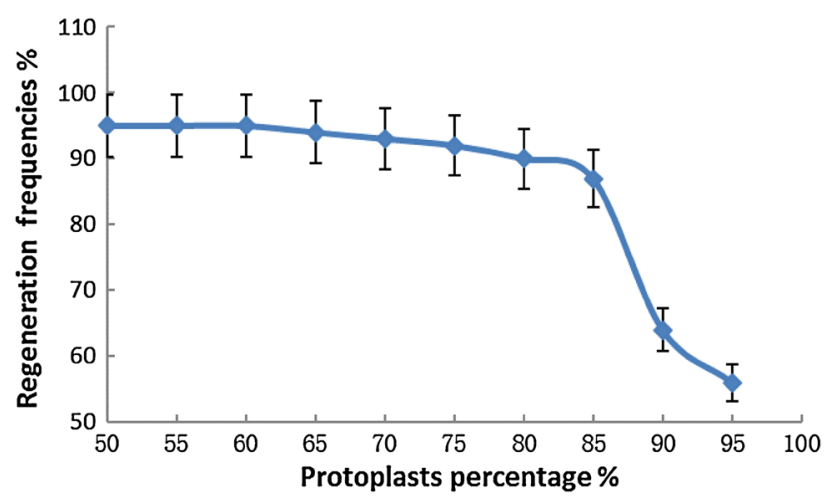

Fig. 4 Relationship between regeneration frequencies and protoplasts concentration

Table 1 Effect of hygromycin concentration on the regeneration of S. cerevisiae protoplasts

\begin{tabular}{ll}
\hline Hygromycin B concentration $\left(\mathrm{mg}^{-1}\right)$ & Colony (numbers) \\
\hline 0 & $362 \pm 47$ \\
50 & $211 \pm 34$ \\
100 & $163 \pm 16$ \\
150 & $44 \pm 7$ \\
200 & 0 \\
250 & 0 \\
\hline
\end{tabular}

hygromycin B exceeded $200 \mathrm{mg} \mathrm{1}^{-1}$. In view of the inhibitory effect of hygromycin B on S. cerevisiae protoplast activity, a hygromycin B concentration of $200 \mathrm{mg} \mathrm{l}^{-1}$ was used to screen transformants harboring the sestc expression vector. Bi-functional expression vectors were constructed in which the phosphoglycerate kinase gene was fused to the hygromycin B resistance gene (Kaster et al. 1984). A hygromycin B concentration of $200 \mathrm{mg} \mathrm{l}^{-1}$ was sufficient to inhibit the growth of $S$. cerevisiae in solid agar plates. In this study, S. cerevisiae cells harboring the expression vector harboring the sestc gene and the hygromycin B resistance gene were found to be resistant to high levels of hygromycin $\mathrm{B}$.

\section{Screening of transformants and molecular identification}

PCR amplification was used for analysis of DNA extracted from the transformants (Fig. 5). The electrophoresis data show that the entire genome was amplified. In lanes 11 and 12 , no DNA was visualized, whereas other lanes showed bright bands. Colonies corresponding to PCR products in lanes 2, 6, 9, and 10, in which bright bands could be visualized, were selected for further analysis. The PCR results indicated that the percentage of positive transformants was $85.4 \%$, which represented the vast majority of colonies on solid screening media.

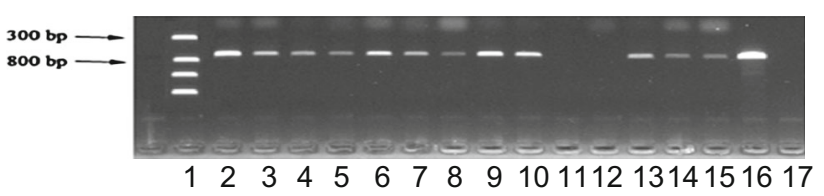

Fig. 5 Electrophoretic resolution of PCR-amplified DNA extracted from the transformant colonies Lane 1 DNA marker, Lanes 2-15 transformants, Lane 16 positive control, Lane 17 negative control

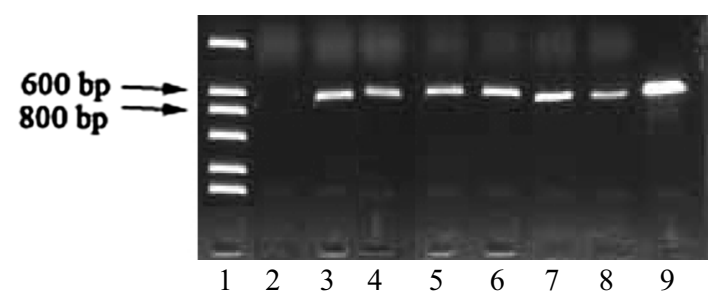

Fig. 6 Detection of sestc expression using RT-PCR. Lane 1 marker, 3-8 transformants, Lane 9 positive control, Lane 2 negative control

Reverse transcriptase-polymerase chain reaction (RTPCR) was used to verify the transformants, based on the analysis of sestc expression (Fig. 6). After the preparation of RNA and synthesis of cDNA, PCR was performed to amplify the cDNA product using the designed primers. Positive transformants were identified by agarose gel electrophoresis, which indicated that $90.1 \%$ of the transformants were positive. RT-PCR has been previously used to assess the expression of candidate genes in $S$. cerevisiae (Basso et al. 2015). In addition, RT-PCR has been used for the evaluation of a vector for multi-copy integration into the $S$. cerevisiae chromosome and to confirm high-copy integration events (Tripathi et al. 2012). In this study, RTPCR was used for further verification of the positive transformant.

\section{The "transparent circle" method}

To evaluate the effect of transformation and expression of the cellulase-encoding gene further, the transformants were grown on solid sodium carboxymethyl cellulose medium. After incubation for 6-8 h, results indicated the formation of transparent circles of various sizes on the Petri dish. In Fig. 7, the bright middle zone was perforated using a puncher to form a hole. The transparent circle formed due to the activity of cellulase was viewed as an innermost bright zone surrounding the hole. The darker outermost zone around the hole represented the region of the solid medium in which no enzymatic activity had occurred. Figure 7 shows the sizes of the transparent circle sizes for recombinant transformants numbers 11,14 , and 27 as well as the wild-type strain. The transformants were found to be capable of expressing cellulase, whereas the wild-type strain was not, as indicated by the absence of a transparent 


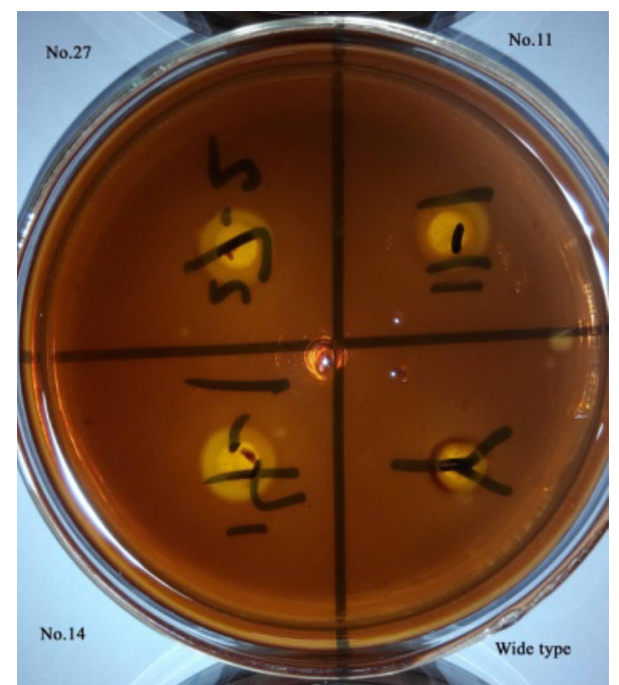

Fig. 7 Transparent circle on a stained sodium carboxymethyl cellulose plate on which $S$. cerevisiae transformants and the wild-type strain had been cultured

Table 2 Sizes of the transparent circles formed in the $S$. cerevisiae transformant culture and wild-type culture on solid medium

\begin{tabular}{lll}
\hline Strain & $\begin{array}{l}\text { Size of } \\
\text { transparent } \\
\text { circle }(\mathrm{mm})\end{array}$ & $\begin{array}{l}\text { Fold-difference } \\
\text { compared with } \\
\text { that of wild-type }\end{array}$ \\
\hline Transformant number 11 & $4.21 \pm 0.54$ & 35.1 \\
Transformant number 14 & $7.65 \pm 0.98$ & 63.8 \\
Transformant number 27 & $4.55 \pm 0.48$ & 37.9 \\
Transformant number 36 & $4.62 \pm 0.35$ & 38.5 \\
Transformant number 37 & $5.02 \pm 0.41$ & 41.8 \\
Transformant number 59 & $5.59 \pm 0.55$ & 46.6 \\
Transformant number 60 & $6.23 \pm 0.28$ & 51.9 \\
Transformant number 66 & $5.68 \pm 0.45$ & 47.3 \\
Transformant number 69 & $6.84 \pm 0.87$ & 57 \\
Wild-type & $0.12 \pm 0.01$ & - \\
\hline
\end{tabular}

circle in solid medium in which the latter was grown. The "transparent circle" method has been used to isolate strains capable of degrading straw with high efficiency (Philippidis and Hatzis 1997). In this study, this method was used to investigate the ability of the present strains to produce cellulase.

The sizes of the transparent circle were calculated based on a formula (Fig. 2). The transparent circle produced by the wild-type strain was small, whereas those produced by the transformants were significantly larger (Table 2); the largest of these, which measured $7.65 \mathrm{~mm}$ in diameter and was 63.8-fold larger than that of the wild-type, was produced by transformant number 14 . The transparent circle experiment showed that the cellulase activity of the transformants was significantly higher than that of the wild-type strain, confirming that the sestc gene is highly expressed in S. cerevisiae and that the cellulase enzyme encoded by this gene is secreted from the cell.

\section{Comparison of the expression of the cellulase system by the transformant grown in fermentation culture and by the wild-type strain}

Saccharomyces cerevisiae strains capable of simultaneously producing and secreting several heterologous cellulases are highly useful for applications such as consolidated bioprocessing. In a previous study, two native $S$. cerevisiae genes, PSE1 and SOD1, were overexpressed under the transcriptional control of the constitutive $p g k 1$ promoter. A dramatic increase (of $447 \%$ ) in $\beta$-glucosidase secretion was observed in the engineered $S$. cerevisiae strain (Kroukamp et al. 2013). However, the method used resulted in enzyme-specific effects, induced by Cel3A secretion, whose activity was greater than that of the other cellulases. To maximize heterologous protein secretion for consolidated bioprocessing, the integration of genes encoding cellulases amenable to expression in engineered $S$. cerevisiae is imperative (Kroukamp et al. 2013). The overexpression of a single cellulase system in the native $S$. cerevisiae strain did not result in enhancement of the total cellulase activity, as secretion was a limiting factor for consolidated bioprocessing in this engineered yeast (Mood et al. 2013). The reporter proteins S. fibuligera BGL was used to investigate the secretion of recombinant proteins in S. cerevisiae (Al-Baghdadi 2003). Moderate to low secretion levels were observed for CBHs (Zaldivar et al. 2001), BGLs (Elia et al. 2008) and EGs (Cavka et al. 2014). Therefore, the production of cellulolytic enzymes via the expression of recombinant cellulase genes was particularly challenging. In this study, assessment of the activity of cellulase enzymes indicated that the heterologous cellulase sestc gene was expressed with high efficiency under the control of the em-gpd promoter. In this study, transformant number 14 was selected to analyze the expression of cellulase and ethanol production. After fermentation for $48 \mathrm{~h}$, the cellulase activity, with wheat bran as fermentation substrate, reached a peak. For $S$. cerevisiae transformant number 14 , following $48 \mathrm{~h}$ of fermentation, the total activity of cellulase (as determined using the filter paper method), endo- $\beta$-D-glucanase, exo- $\beta$-D-glucanase, and xylanase activity was $1.1,378,1.44$, and $164 \mathrm{U} \mathrm{ml}^{-1}$, respectively, which was 27.5-fold (compared with $0.2 \mathrm{U} \mathrm{ml}^{-1}$ ), 63-fold (compared with $30 \mathrm{U} \mathrm{ml}^{-1}$ ), 24-fold (compared with $0.3 \mathrm{U} \mathrm{ml}^{-1}$ ), and 19-fold (compared with $43 \mathrm{U} \mathrm{ml}^{-1}$ ) higher than that of the control (Fig. 8). 

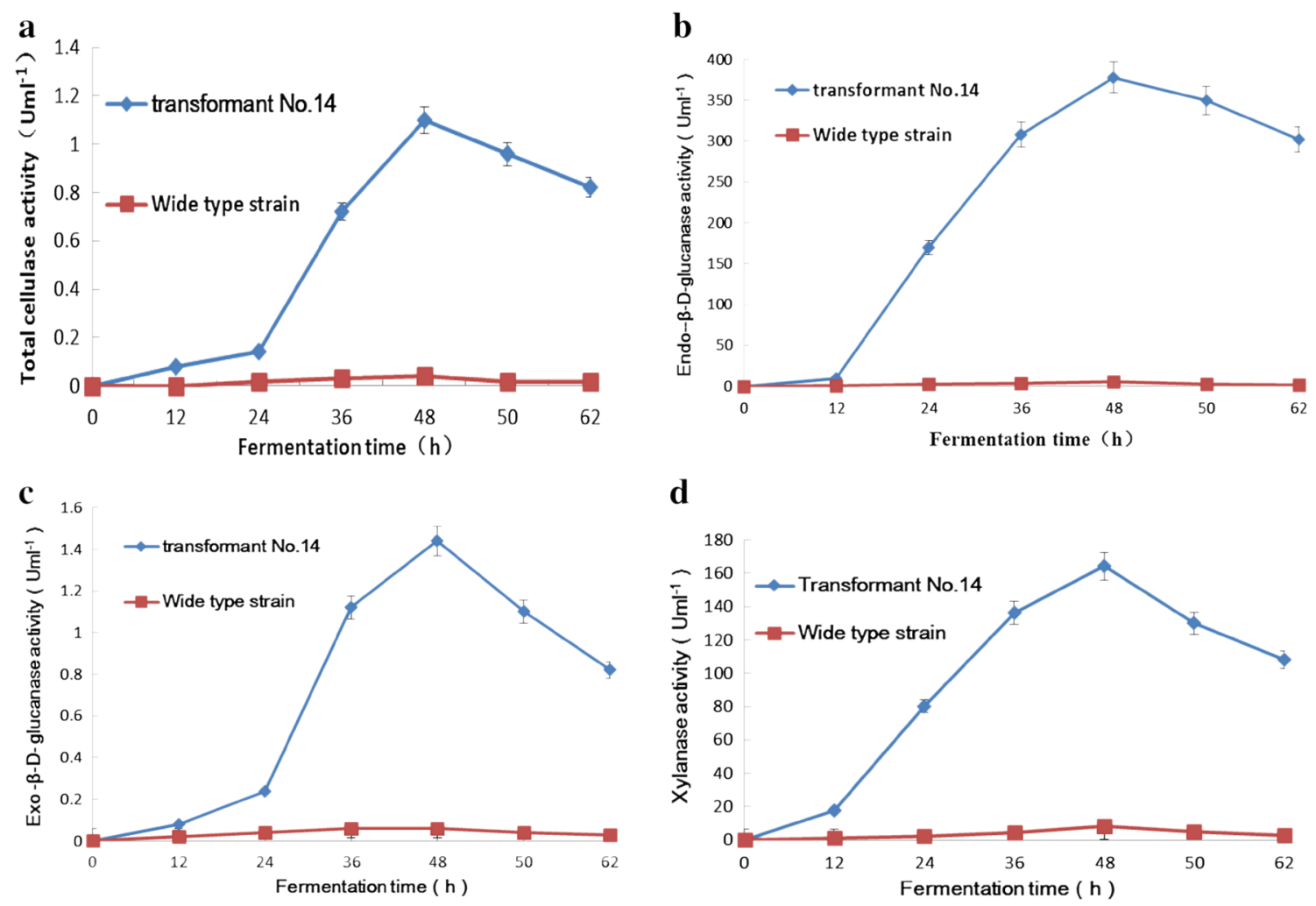

Fig. 8 Lignocellulase activity of recombinant number 14 and the wild-type strain. a Total cellulase activity; b Endo- $\beta$-D-glucanase activity; c Exo- $\beta$-D-glucanase activity; $\mathbf{d}$ xylanase activity

\section{Cellulase characteristics of recombinant $S$. cerevisiae}

The production of bio-ethanol from lignocellulosic biomass represents a promising renewable source of energy. However, the enzymes required for biomass conversion are expensive to obtain. To utilize cellulolytic enzymes comprising a single enzymatic system for such processes, the cellulase and xylanase enzymatic cocktail must be characterized in terms of temperature and $\mathrm{pH}$ (Taneda et al. 2012). In this study, the catalytic efficiency of the engineered $S$. cerevisiae strain, which harbored a heterologous single enzyme system comprising three cellulase activities, required the synergistic interaction of the cellulolytic enzymes. The recombinant $S$. cerevisiae transformant number 14 , which efficiently expressed the sestc gene, was used to investigate the cellulase characteristics of the engineered strain. The optimum reaction temperature and $\mathrm{pH}$ were $50{ }^{\circ} \mathrm{C}$ and $\mathrm{pH} 5$, respectively (Fig. 9a, b). In addition, the exogenous cellulolytic enzyme (sestc) was found to be sensitive to external ambient conditions.

It was observed that the final concentration of reducing sugars during hydrolysis decreased with decreasing enzyme activity. The reaction equilibrium was affected by the catalytic efficiency of the enzyme. Thermal instability of enzymes, feedback inhibition, conversion of the substrate into more recalcitrant structure, and deactivation of enzymes affected the thermal and $\mathrm{pH}$ stability (Farinas et al. 2010). It was found that the enzyme was stable from 20 to $50{ }^{\circ} \mathrm{C}$; at temperatures above $50{ }^{\circ} \mathrm{C}$, enzyme activity decreased significantly (Fig. 10a), whereas low temperatures $\left(20-50{ }^{\circ} \mathrm{C}\right)$ did not affect the thermal stability of the enzyme. The $\mathrm{pH}$ stability was investigated using a citrate buffer solution of $\mathrm{pH} 3-7$, in a water bath, for $5 \mathrm{~h}$ at $50{ }^{\circ} \mathrm{C}$. The cellulase activity of the recombinant $S$. cerevisiae transformant number 14 was found to be stable at $\mathrm{pH} 5$ (Fig. 10b).

The effects of metal ions, such as $\mathrm{K}^{+}, \mathrm{Mn}^{2+}, \mathrm{Zn}^{2+}$, $\mathrm{Cu}^{2+}, \mathrm{Fe}^{2+}$, and $\mathrm{Fe}^{3+}$, on cellulase activity were investigated (Fig. 11). $\mathrm{Cu}^{2+}$ and $\mathrm{Fe}^{2+}$ were found to inhibit total cellulase activity. High ionic concentrations of $\mathrm{Cu}^{2+}$ and $\mathrm{Fe}^{2+}$ led to strong inhibitory effects. Ions $\mathrm{K}^{+}, \mathrm{Mn}^{2+}, \mathrm{Zn}^{2+}$, and $\mathrm{Fe}^{3+}$ were found to increase cellulase activity; the activation effect was the most significant for $\mathrm{Fe}^{3+}$. The total cellulase activity was 2.4 -fold higher than that of the control for $5 \mathrm{mmol} \mathrm{l}^{-1} \mathrm{Fe}^{3+}$. The appropriate concentration (1-5 mmol $\mathrm{l}^{-1}$ ) of $\mathrm{Zn}^{2+}$ was also observed to increase cellulase activity; at a concentration of $5 \mathrm{mmol} \mathrm{l}^{-1}$ of $\mathrm{Zn}^{2+}$, the total cellulase activity was 1.42 -fold higher than that of the control. At concentrations above $5 \mathrm{mmol}^{-1}$ $\mathrm{Zn}^{2+}$, the cellulase activity increased gradually; however, 
at excessively high concentrations $\left(30-35 \mathrm{mmol} \mathrm{l}^{-1}\right)$ of $\mathrm{Zn}^{2+}$, a decline in cellulase activity was observed. At a concentration of $25 \mathrm{mmol} \mathrm{l}^{-1}$ of $\mathrm{Zn}^{2+}$, the cellulase activity was nearly equal to that of the control. At $0.25 \mathrm{mmol} \mathrm{l}^{-1}, \mathrm{~K}^{+}$and $\mathrm{Mn}^{2+}$ produced an equal increase in total cellulase activity. The effect of metal ions on the enzyme was similar to that of acid catalysis, which is involved in oxidation-reduction reactions. In addition, metal ions may exert induction effects on enzyme production due to their electronegativity. The mechanisms underlying inhibition and activation were significantly different. The lower electronegativity of $\mathrm{K}^{+}$is more beneficial for binding of enzyme to substrate, which results in an increase in the activity of the enzyme. $\mathrm{Cu}^{2+}$, a heavy metal ion, may cause denaturation of proteins. The toxic effects of high concentrations of heavy metal ions, such as $\mathrm{Cu}^{2+}$, are particularly evident.

\section{In situ fermentation for ethanol production}

Reducing sugars were released from the natural substrate when the reaction temperature was $50{ }^{\circ} \mathrm{C}$ for $2 \mathrm{~h}$. At
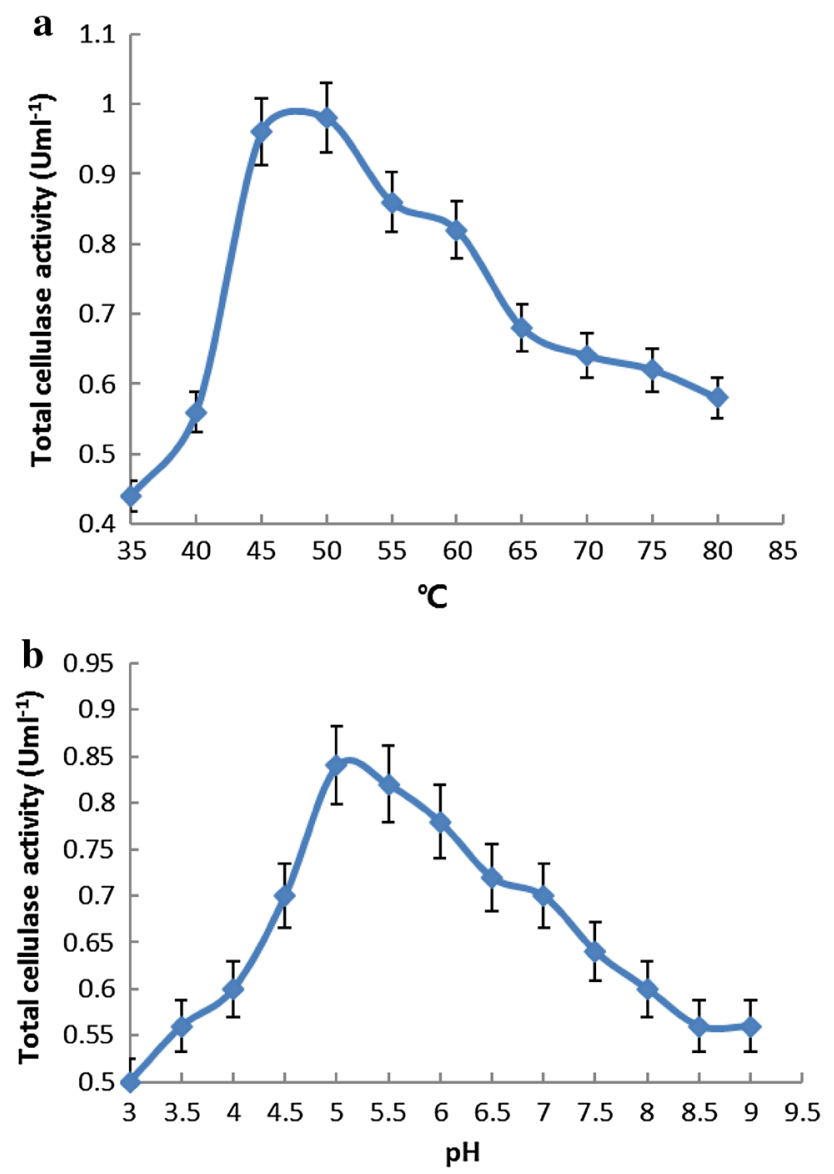

Fig. 9 Optimal reaction temperature (a) and $\mathrm{pH}$ (b) for the cellulases of recombinant transformant number 14
$50{ }^{\circ} \mathrm{C}$, microbial activity was inhibited. After thermal treatment, however, the temperature returned to $30{ }^{\circ} \mathrm{C}$; at this temperature, the yeast mainly utilized reducing sugars as the substrate for ethanol production. In this study, ethanol production by the wild-type and recombinant $S$. cerevisiae strains was investigated. For the recombinant $S$. cerevisiae strain, the initial concentration of reducing sugars was higher than that of the wild-type strain, owing to the release of significant amounts of reducing sugars from recalcitrant lignocelluloses crystals due to the action of cellulases. The concentrations of reducing sugar, released by the recombinant $S$. cerevisiae and the wild-type strain, were 12.5 and $0.7 \mathrm{gl}^{-1}$, respectively, and the initial concentrations of ethanol were $1.2 \mathrm{gl}^{-1}$ (Fig. 12a) and $0.11 \mathrm{gl}^{-1}$ (Fig. 12b), respectively. The maximal level of ethanol production was achieved by the recombinant $S$. cerevisiae strain following $16 \mathrm{~h}$ of fermentation. Then, the concentration of residual ethanol gradually decreased to $0.3 \mathrm{gl}^{-1}$ following a further $32 \mathrm{~h}$ of fermentation. During ethanol production, the concentration of the residual reducing sugar decreased gradually to $5.1 \mathrm{gl}^{-1}$. For the wild-type $S$. cerevisiae, the initial concentration of residual
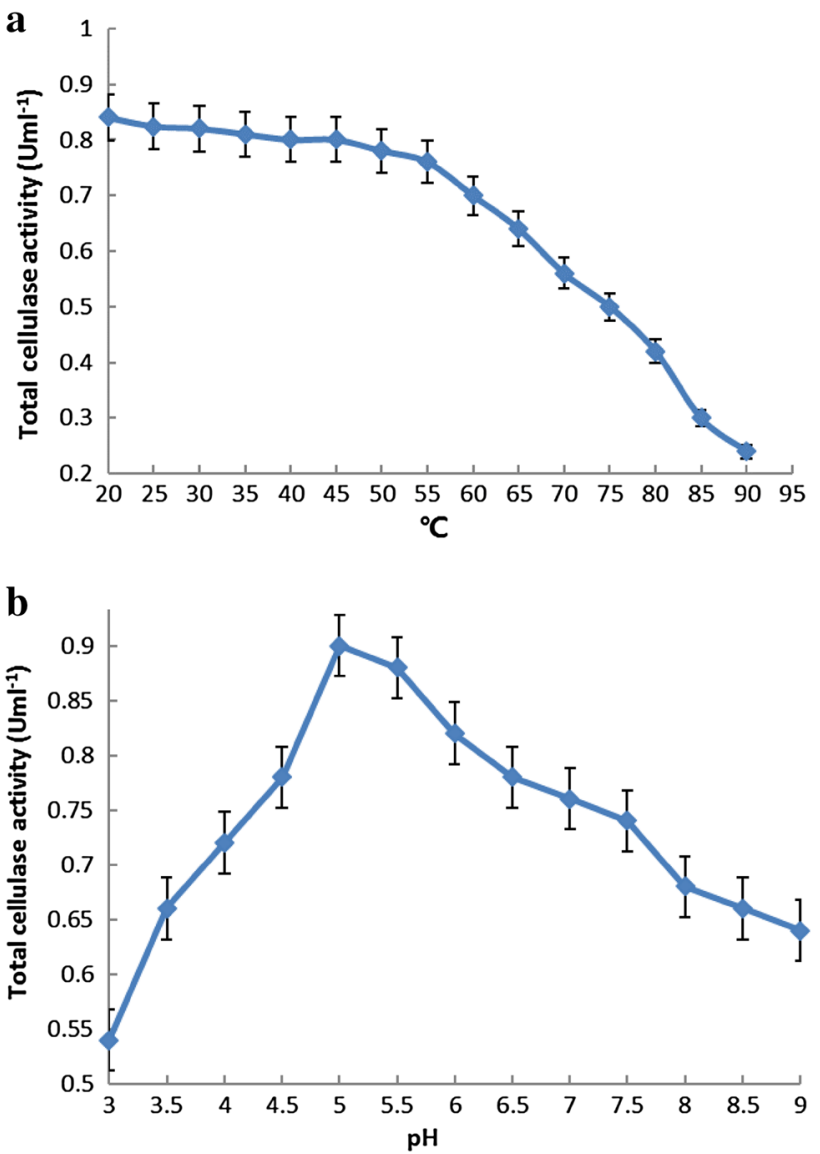

Fig. 10 Thermal (a) and $\mathrm{pH}$ (b) stability of recombinant transformant number 14 crude cellulase 
Fig. 11 Effects of ion concentration on total cellulase activity of the $S$. cerevisiae sestc transformant

Fig. 12 Relationship between the consumption of reducing sugar and ethanol concentration $\mathbf{a}$ for the transformant; $\mathbf{b}$ for the wild-type $S$. cerevisiae strain; during subsequent fermentation, ethanol production increased until $8 \mathrm{~h}$ of fermentation, then gradually decreased at 8-32 $\mathrm{h}$ of fermentation
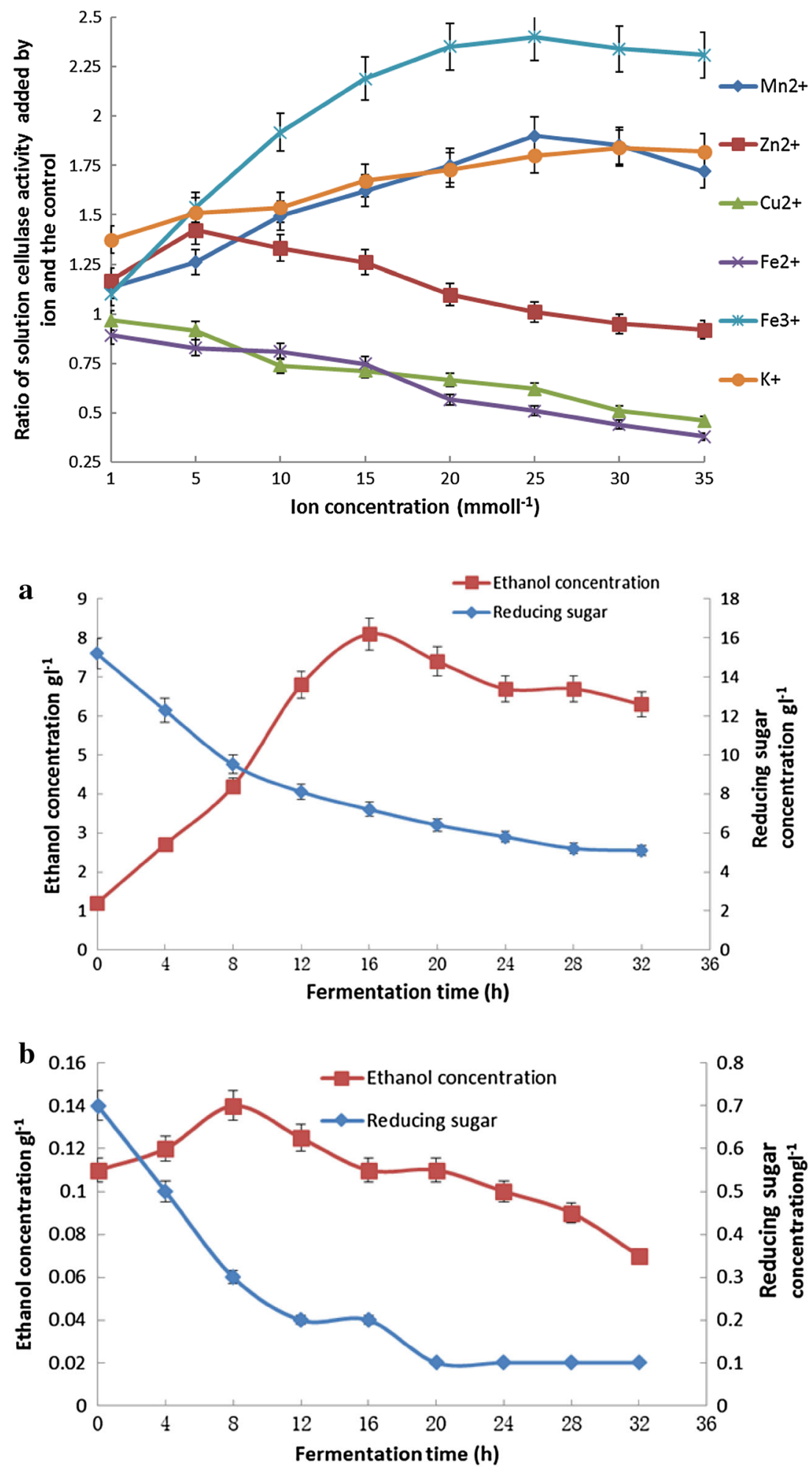

reducing sugar was $0.7 \mathrm{gl}^{-1}$, which was attributed to the low expression of cellulase expressed by this strain. Subsequent fermentation involved the consumption of reducing sugar; the final concentration of which was observed to be about $0.1 \mathrm{gl}^{-1}$ (Fig. 12b).

\section{Conclusions}

An eukaryotic expression vector carrying a single-enzymesystem-three-cellulase gene (sestc) was genetically integrated into the $S$. cerevisiae genome using the protoplast 
method. Several recombinant strains of $S$. cerevisiae, capable of expressing cellulase with high efficiency, were selected. The total activity of cellulase, endo- $\beta$-D-glucanase, exo- $\beta$-D-glucanase, and xylanase of the recombinant $S$. cerevisiae transformant number 14 were $1.1,378$, 1.44 , and $164 \mathrm{U} \mathrm{ml}^{-1}$, respectively, which were $27.5-, 63-$, 24-, and 19-fold higher than those of the control. The concentrations of ethanol produced by the engineered $S$. cerevisiae strain and the wild-type were 8.1 and $0.14 \mathrm{gl}^{-1}$, with wheat bran as the carbon source, under submerged conditions.

This study provided an alternative method for the production of bio-ethanol by adopting the mechanism of consolidated bioprocessing without the addition of the cellulase and xylanase derived from other microorganisms. This method achieved true in situ saccharification and fermentation and would thus substantially save costs during the cellulase production and saccharification process. However, some potential limitations should first be addressed, such as the difference in optimal temperature between cellulase production by the fermentation and saccharification process and low expression activity of the cellulase gene leading to low conversion efficiency of lignocellulosic bio-ethanol. Further studies should focus on the domestication of an engineered strain to increase cellulase activity, optimization of the promoter to promote the expression of heterogeneous genes, and thermal tolerance of $S$. cerevisiae at $50{ }^{\circ} \mathrm{C}$ to enhance the application value of engineered strains of $S$. cerevisiae.

Acknowledgments We gratefully acknowledge funding from the Anhui Natural Science Foundation (1408085MC67) and the Anhui Key Technology Research and Development Program (1604a0702001).

Open Access This article is distributed under the terms of the Creative Commons Attribution 4.0 International License (http:// creativecommons.org/licenses/by/4.0/), which permits unrestricted use, distribution, and reproduction in any medium, provided you give appropriate credit to the original author(s) and the source, provide a link to the Creative Commons license, and indicate if changes were made.

\section{References}

Al-Baghdadi MAS (2003) Hydrogen-ethanol blending as an alternative fuel of spark ignition engines. Renew Energy 28(9):1471-1478. doi:10.1016/S0960-1481(02)00188-X

Baek SH, Kim S, Lee K, Lee JK, Hahn JS (2012) Cellulosic ethanol production by combination of cellulase-displaying yeast cells. Enzym Microb Technol 51(6-7):366-372. doi:10.1016/j. enzmictec.2012.08.005

Basso LR, Gast CE, Igor B, Brian W (2015) Identification and properties of plasma membrane azole efflux pumps from the pathogenic fungi Cryptococcus gattii and Cryptococcus neoformans. J Antimicrob Chemother 70(5):1396-1407. doi:10.1093/jac/dku554

Cavka A, Alriksson B, Rose SH, Zyl WHV, Jönsson LJ (2014) Production of cellulosic ethanol and enzyme from waste fiber sludge using SSF, recycling of hydrolytic enzymes and yeast, and recombinant cellulase-producing Aspergillus niger. J Ind Microbiol Biotechnol 41(8):1191-1200. doi:10.1007/s10295014-1457-9

Elia TP, Oliva JM, Mercedes B, Lisbeth O (2008) Comparison of SHF and SSF processes from steam-exploded wheat straw for ethanol production by xylose-fermenting and robust glucosefermenting Saccharomyces cerevisiae strains. Biotechnol Bioeng 100(6):1122-1131. doi:10.1002/bit.21849

Farinas CS, Loyo MM, Junior AB, Tardioli PW, Neto VB, Couri S (2010) Finding stable cellulase and xylanase: evaluation of the synergistic effect of $\mathrm{pH}$ and temperature. New Biotechnol 27(6):810-815. doi:10.1016/j.nbt.2010.10.001

Fujita Y, Takahashi S, Ueda M, Tanaka A, Okada H, Morikawa Y, Kawaguchi T, Arai M, Fukuda H, Kondo A (2002) Direct and efficient production of ethanol from cellulosic material with a yeast strain displaying cellulolytic enzymes. Appl Environ Microbiol 68(10):5136-5141. doi:10.1128/AEM.68.10.51365141.2002

Fujita Y, Ito J, Ueda M, Fukuda H, Kondo A (2004) Synergistic saccharification, and direct fermentation to ethanol, of amorphous cellulose by use of an engineered yeast strain codisplaying three types of cellulolytic enzyme. Appl Environ Microbiol 70(2):1207-1212. doi:10.1128/AEM.70.2.1207-1212.2004

Haan RD, Rose SH, Lynd LR, Zyl WHV (2007) Hydrolysis and fermentation of amorphous cellulose by recombinant Saccharomyces cerevisiae. Metab Eng 9(1):87-94. doi:10.1016/j. ymben.2006.08.005

Haan RD, Kroukamp H, Zyl JHDV, Zyl WHV (2013) Cellobiohydrolase secretion by yeast: current state and prospects for improvement. Process Biochem 48(1):1-12. doi:10.1016/j. procbio.2012.11.015

Hong J, Tamaki H, Yamamoto K, Kumagai H (2003) Cloning of a gene encoding thermostable cellobiohydrolase from Thermoascus aurantiacus and its expression in yeast. Appl Microbiol Biotechnol 63(1):42-50. doi:10.1007/s00253-003-1379-3

IUPAC (1987) Measurement of cellulase activities. Pure Appl Chem 59(2):257-268

Kaster KR, Burgett SG, Ingolia TD (1984) Hygromycin B resistance as dominant selectable marker in yeast. Curr Genet 8(5):353-358. doi:10.1007/BF00419824

Katahira S, Fujita Y, Mizuike AH, Kondo A (2004) Construction of a xylan-fermenting yeast strain through codisplay of xylanolytic enzymes on the surface of xylose-utilizing Saccharomyces cerevisiae cells. Appl Environ Microbiol 70(9):5407-5414. doi:10.1128/AEM.70.9.5407-5414.2004

Kotaka A, Bando H, Kaya M, Kato-Murai M, Kuroda K, Sahara H, Hata Y, Kondo A, Ueda M (2008) Direct ethanol production from barley beta-glucan by sake yeast displaying Aspergillus oryzae beta-glucosidase and endoglucanase. J Biosci Bioeng 105(6):622-627. doi:10.1263/jbb.105.622

Kroukamp H, Haan RD, Wyk NV, Zyl WHV (2013) Overexpression of native PSE1 and SOD1 in Saccharomyces cerevisiae improved heterologous cellulase secretion. Appl Energy 102(2):150-156. doi:10.1016/j.apenergy.2012.05.062

Lynd LR, Zyl WHV, Mcbride JE, Laser M (2005) Consolidated bioprocessing of cellulosic biomass: an update. Curr Opin Biotechnol 16(5):577-583. doi:10.1016/j.copbio.2005.08.009

Mood SH, Golfeshan AH, Tabatabaei M, Jouzani GS, Najafi GH, Gholami M, Ardjmand M (2013) Lignocellulosic biomass to bioethanol, a comprehensive review with a focus on 
pretreatment. Renew Sustain Energy Rev 27(6):77-93. doi:10. 1016/j.rser.2013.06.033

Nummi M, Perrin JM, Niku-Paavola ML, Enari TM (1985) Measurement of xylanase activity with insoluble xylan substrate. Biochem J 226(2):617-620. doi:10.1042/bj2260617

Philippidis GP, Hatzis C (1997) Biochemical engineering analysis of critical process factors in the biomass-to-ethanol technology. Biotechnol Prog 13(3):222-231. doi:10.1021/bp970017u

Rensburg PV, Zyl WHV, Pretorius IS (1998) Engineering yeast for efficient cellulose degradation. Yeast 14(14):67-76. doi:10.1002/ (SICI)1097-0061(19980115)14:1<67:AID-YEA200>3.0.CO;2-T

Rikhvanov EG, Varakina NN, Rusaleva TM, Rachenko EI, Voinikov VK (2003) The absence of a direct relationship between the ability of yeasts to grow at elevated temperatures and their survival after lethal heat shock. Microbiology 72(4):423-427. doi:10.1023/a:1025036505147

Saini R, Saini JK, Adsul M, Patel AK, Mathur A, Tuli D, Singhania RR (2015) Enhanced cellulase production by Penicillium oxalicum for bio-ethanol application. Bioresour Technol 188:240-246. doi:10.1016/j.biortech.2015.01.048

Shujie C, Peizhou Y, Liqiong G, Junfang L, Nannan L (2009) Expression of multi-functional cellulase gene mfc in Coprinus cinereus under control of different basidiomycete promoters. Bioresour Technol 100(19):4475-4480. doi:10.1016/j.biortech. 2009.04.021

Sree NK, Sridhar M (1999) Ethanol production in solid substrate fermentation using thermotolerant yeast. Process Biochem 34(2):115-119. doi:10.1016/S0032-9592(98)00074-0

Svoboda A (1966) Regeneration of yeast protoplasts in agar gels. Exp Cell Res 44(2):640-642. doi:10.1016/0014-4827(66)90473-3

Taneda D, Ueno Y, Ikeo M, Okino S (2012) Characteristics of enzyme hydrolysis of cellulose under static condition. Bioresour Technol 121(2):154-160. doi:10.1016/j.biortech.2012.06.104

Tang H, Hou J, Shen Y, Xu L, Yang H, Fang X, Bao X (2013) High $\beta$-glucosidase secretion in Saccharomyces cerevisiae improves the efficiency of cellulase hydrolysis and ethanol production in simultaneous saccharification and fermentation. J Microbiol Biotechnol 23(11):1577-1585. doi:10.4014/jmb.1305.0501
Tiboni M, Grzybowski A, Baldo GR, Dias EF, Tanner RD, Kornfield JA, Fontana JD (2014) Thermopressurized diluted phosphoric acid pretreatment of ligno(hemi)cellulose to make free sugars and nutraceutical oligosaccharides. $J$ Ind Microbiol 41(6):957-964. doi:10.1007/s10295-014-1426-3

Tripathi K, Matmati N, Zzaman S, Westwater C, Mohanty BK (2012) Nicotinamide induces Fob1-dependent plasmid integration into chromosome XII in Saccharomyces cerevisiae. FEMS Yeast Res 12(8):949-957. doi:10.1111/j.1567-1364.2012.00844.x

Walsum GPV, Lynd LR (1998) Allocation of ATP to synthesis of cells and hydrolytic enzymes in cellulolytic fermentative microorganisms: Bioenergetics, kinetics, and bioprocessing. Biotechnol Bioeng 58(2-3):316-320. doi:10.1002/(SICI)10970290(19980420)58:2/3<316:AID-BIT31>3.3.CO;2-N

Yamada R, Taniguchi N, Tanaka T, Ogino C, Fukuda H, Kondo A (1978) Cocktail $\delta$-integration: a novel method to construct cellulolytic enzyme expression ratio-optimized yeast strains. Microb Cell Fact 35(1):172-178. doi:10.1186/1475-2859-9-32

Yang P, Guo L, Cheng S, Lou N, Lin J (2011) Recombinant multifunctional cellulase activity in submerged fermentation of lignocellulosic wastes. Renew Energy 36(12):3268-3272. doi:10.1016/j.renene.2011.04.019

Zaldivar J, Nielsen J, Olsson L (2001) Fuel ethanol production from lignocellulose: a challenge for metabolic engineering and process integration. Appl Microbiol Biotechnol 56(1-2):17-34. doi:10.1007/s002530100624

Zerva A, Savvides AL, Katsifas EA, Karagouni AD, Hatzinikolaou DG (2014) Evaluation of Paecilomyces variotii potential in bioethanol production from lignocellulose through consolidated bioprocessing. Bioresour Technol 162(162C):294-299. doi:10. 1016/j.biortech.2014.03.137

Zhang YHP, Hong J, Ye X (2009) Cellulase assays. Methods Mol Biol 581:213-231. doi:10.1007/978-1-60761-214-8_14

Zhang C, Zong H, Zhuge B, Lu X, Fang H, Zhu J, Zhuge J (2016) Protoplast preparation and polyethylene glycol (PEG)-mediated transformation of Candida glycerinogenes. Biotechnol Bioprocess Eng 21(1):95-102. doi:10.1007/s12257-015-0686-8 